\title{
Editorial
}

\section{Democracy and the Union: Dressing up Cinderella.}

'The functioning of the Union shall be founded on representative democracy.' This the new Union Treaty echoes from the Constitutional Treaty. 'Citizens are directly represented at Union level in the European Parliament.' It means that the Union pretends to be a democracy and challenges the thesis, held by some, that democracy cannot be applied to an international organisation. The mere ambition does not, however, answer the Union's shortcomings in terms of democracy.

True, the European Parliament is steadily pulling greater weight in the legislative process. Its role in the recent creation of the Services Directive is convincing in this respect. The Parliament is even getting a firmer grip on the executive status and work of the Commission, witness the Santer and Buttiglione episodes. A political life is emerging.

The Parliament's representative capacity alone, however, will not bear the full burden of EU legitimacy in the foreseeable future.

On a formal level, this is owing mainly to two factors. There is the weakness of the Parliament's position vis-à-vis the leading executive body in the Union system, the European Council. There is its absence from a number of legislative procedures, notably from the creation of primary Union law, to wit amendment of the Union treaties and enlargement.

These formal factors are mostly expressions of shortcomings on the substantive or real level, as signalled in the well-known Brunner judgment of the German Verfassungsgericht almost fifteen years ago. They are related to the lack of a common public sphere, of a shared basis of communication, of a common day-to-day experience among the peoples of the Union.

Representative democracy does not stop at the parliamentary channel. The new treaty rightly refers to channels of representative democracy to be found in the domestic polities of the member states via the executive channel.

Member States are represented in the European Council by their Heads of State or Government and in the Council by their governments, themselves democratically accountable either to their national Parliaments, or to their citizens. 
The last four words were included during the Convention to express the French president's accountability to the French citoyens via his or her election. It is an interesting addition, as will appear below.

Such channels of executive representation may presently have greater capacity than the European parliamentary one. But they have proven too indirect to remedy the shortcomings of the European parliamentary channel.

The same goes for the national parliaments' capacities of scrutiny at the European level, on which some hope is presently staked under the new subsidiarity protocol. In European affairs, so far, national parliaments have often cosied up to their respective governments and stretched their relationship with the electorates to the breaking point. This is so even in countries with solid scrutiny practices, such as the UK or Denmark.

There are notable exceptions. Member state parliamentary scrutiny and legislative autonomy have been quite significant in the creation and the subsequent transposition of the notorious European Arrest Warrant legislation. This also demonstrates, conversely, that it is hard to get member states' parliaments involved in Europe's governing structure in any other way than incidentally. ${ }^{1}$

Apart from these forms of indirect democracy, the new treaty will pay tribute to the familiar forms and channels of 'participatory democracy'. These accessory forms, however, are often better at attracting and involving insiders than the public at large.

But there is always direct democracy. Direct democracy is 'the eternal Cinderella of European public law' in the epithet coined by R.C. van Caenegem. ${ }^{2}$ We tend to ignore it too easily. It may be time for its rediscovery in the context of the European Union.

Direct democracy allows the public a direct choice on a substantive or personal issue. It is often seen nowadays as taking one of three forms: popular initiative, referendum and recall. The first is present in the new treaty as the citizen's initiative. ${ }^{3}$ Referendum and recall are missing. But there may be more in store than directly meets the eye.

First, in view of their recently proven immense significance, national referendums about Union treaties are a case in point. They may be understood as the return of the public, to paraphrase a French saying, 'chase the public and it'll return in a gallop.'

${ }^{1}$ Cf. Olaf Tans, Carla Zoethout, Jit Peters (eds.), National Parliaments and European Democracy. A Bottom Up Approach to European Constitutionalism, Groningen 2007, p. 244.

${ }^{2}$ An Historical Introduction to Western Constitutional Law, Cambridge, 1995, p. 274.

3 See Andreas Auer, 'European Citizens' Initiative', EuConst I, 2005, p. 79-86

4 'Chassez le naturel et il revient au galop'. Philippe Néricault, or Destouches. 
Can a national referendum be a form, or an element, of direct democracy in Europe? To be sure, it is extremely primitive and partial and it has no formal status under EU law. Still, the answer can be yes. If, in crucial decisions for the EU, a direct voice is given to a well defined part of the public, then that may be seen as a form of direct democracy.

Indeed, the Dutch prime minister repeatedly asserted that the Dutch no-vote expressed a Europe-wide popular sentiment.

The new Union Treaty will already acknowledge the national parliaments' involvement in the Union 'by [their] taking part in the revision procedures of the Treaties .... ${ }^{5}$ This is a partial codification of the existing referral to 'national constitutional procedures' for the approval of a number of Union decisions.

If we acknowledge, expressly, the role of national parliaments severally in EU democracy, like we acknowledge the role (or even mandate) of domestic courts severally under EU law, why not acknowledge a role for the national bodies of voters in referendum, if called upon under their constitutions? ${ }^{6}$

One step further: once we include national referendums in the Union panoply of (direct) democracy, why not include national elections?

Consider the election of Mr Sarkozy to the French presidency. A presidential election often has a plebiscitary character and thus contains elements of direct democracy. The present case is especially relevant.

Sarkozy was elected on a platform including the point of not having a referendum on the new ('simplified') treaty. His election consequently was a public approval of that position. ${ }^{7}$

In this way, Sarkozy combined his European and his French responsibilities and was awarded a convincing victory by the French public.

As Sarkozy demonstrated, an election may even be seen as a way to trump a previous referendum result, a 'higher instance' or form of appeal in terms of direct democracy. This is so if and when the election, apart from mandating a person, is also a direct expression of the popular will on concrete issues.

Domestic elections thus may be seen, in part, as forms of direct democracy effective both at the domestic and at the European level.

Now, finally, what about European elections? If domestic elections may have elements of direct democracy effective at the European level, a fortiori so for European elections. German Chancellor Ms Angela Merkel was in a hurry to clinch a deal on the new treaty during her presidency. She wants the new treaty in force by

${ }^{5}$ Art. 8c(d) in the European Council IGC mandate of 22 June 2007.

${ }^{6}$ For the courts' mandate, see the book review section of this issue of EuConst.

${ }^{7}$ Even if his qualification of 'simplified' (traité simplifié) for the new treaty has turned into irony, to say the least. 
Spring 2009, before the European Parliament's election. This was in clear defiance of a wide sentiment that Europe is being rushed upon us.

The greater haste, the less speed, as they say. What if the new treaty will not have been cleared by 2009? It might then become a major issue in these European elections. The opponents would be drawn and forced to show their cards, breaking up their closed front and falling out to their two sides. The European public would be called to express itself on the treaty in a single election.

Apart from boosting the European Parliament's status and the public's role in the approval of new EU treaties, it might be a way of really dressing up the Cinderella of direct democracy for its European ball.

This is not a plea; one cannot plead for eventuality. It is a thought experiment. What we only hope is to rediscover direct democracy as a fresh subject of scholarly attention in the context of the European Union.

WTE/MC 